\title{
Urgency of Suspect Determining In the Investigation Process on Human Rights Perspective
}

\section{Suwarno*) and Sri Endah Wahyuningsih**)}

*) Student of Masters (S2) of Law Faculty of Law Unissula and Police Officer in Polres of Pati, Central Java, email: warno5961@gmail.com

${ }^{* *}$ Faculty of Law, Universitas Islam Sultan Agung (UNISSULA) Semarang

\begin{abstract}
.
Protection of suspect rights related to human rights protection. In the Criminal Procedure Code Investigators are given the authority for forced attempts in the form of arrest, detention, confiscation and so on. If a person is named a suspect, he is confronted by the investigator whose job it is to find, collect evidence about the criminal act that occurred. The purpose of this study 1. To analyze the determination of suspects 2. To analyze the obstacles faced by law enforcers and their solutions. The research methods used are 1. Approach method 2. Type or research specifications 3. Types of data and data sources 4. Data collection methods 5. Data analysis methods. And the conclusions in this study are 1. The implementation of the determination of the suspect, that the legality of the determination of the suspect in the investigation process can be recognized if the rights of the suspect are fulfilled. $a$. The investigator can only determine the status of a suspect after the results of the investigation have obtained sufficient initial evidence of at least 2 (two) types of evidence. $b$. to determine sufficient preliminary evidence by means of a case title. 2. Constraints faced by law enforcers related to the determination of suspects and the solutions are a. suspects often provide complicated statements in front of investigators and removing evidence will take time to reveal the criminal acts committed. $b$. the summons of witnesses, victims and experts are often not on time c. Lack of budget support. The solution to these constraints is a. in the future, operational funds for witnesses who are summoned are needed to provide information so as to facilitate the investigation process. $b$. the need for regulations that limit the length of time a person has the status of a suspect to avoid potential human rights violations and to provide legal certainty for justice seekers.

Keywords: Determination; Suspects; Human Rights.
\end{abstract}

\section{Introduction}

The legal certainty is a very meaningful right of everyone and must be fulfilled when dealing with legal processes, because only in this way will people believe in the law itself. Amendments to the 1945 Constitution concerning human rights (HAM) relating to legal protection, especially the rights of suspects. ${ }^{1}$

The guarantee and protection of human rights in criminal procedural law rules has a very important meaning, because in large part in the framework of the process of this criminal procedural law it leads to the limitations of human rights such as arrest, detention, confiscation, search and punishment which is essentially the limitation of human rights. ${ }^{2}$

1 https://media.neliti.com/media/publications/12327-ID-tinjau-yuridis-hak-hak-tersangka-dalampemeriksa-pendahuluan.pdf, accessed on March 29, 2020

2 Erni Widhayanti, 1998, Hak-Hak Tersangka / Terdakawa di Dalam KUHAP, Liberty Yogyakarta, p. 34. 
In the Criminal Procedure Code Investigators are given the authority to make forced efforts in the form of arrest, detention, examination, confiscation and so on. The task of the investigator is to carry out investigations in a manner regulated in the Criminal Procedure Code (KUHAP). When a person is declared a suspect, he must face an investigator whose job is to find and collect evidence about the criminal act that occurred. ${ }^{3}$ Events that also express concrete conditions, such as behavior, gestures or physical attitudes, are more commonly known in actions, actions and actions. ${ }^{4}$ For example: Police Report Number: LP/B/93/I/2020/Central Java/Res PT, dated January 30, 2020, the banking crime case at the Pati Police, Central Java, Determination of the suspect Iwan Rizal Fauji, SE bin Sutikno, legally proven to have committed a banking crime or embezzlement in his position that the suspect's actions have been committed comply with the elements of the offense as referred to in Article: 49 paragraph (1) letter b of Act No. 10 of 1998 concerning Amendment to Act No.7 of 1992 concerning Banking or 374 of the Criminal Code.Offense is listed in the Indonesian dictionary as follows: "Offense is an act that is punishable because it is a violation of the criminal law. A criminal act can be defined as an act that is prohibited by a rule of law, the prohibition which is accompanied by the threat of sanctions in the form of certain crimes. ${ }^{5}$

\section{Research Methods}

This research uses a sociological juridical approach. Juridical means that in this study emphasizes the applicable legal principles based on the aspects of positive legal regulations. Sociology in this study emphasizes the symptoms of law that are not associated with society, with the implementation of a statutory regulation. A sociological juridical approach or empirical legal research is a legal research that uses primary data as the main data. So, the sociological juridical approach in this study means that in analysing the problem it is done by combining legal materials, the theory of law work and the theory of legal objectives.

\section{Results And Discussion}

\subsection{Implementation of the determination of the suspect in the process of investigating a criminal case according to the criminal procedure law in the perspective of protecting human rights}

In essence, the term suspect is the term in the Criminal Procedure Code that is differentiated from the defendant. Unlike the case in the Dutch legal system which is included in the Wetboekvan Strafvordering, it turns out that the terms

\footnotetext{
3 Nico Ngani, Get to know the Criminal Procedure Code for General Affairs and Investigation, https://ejournal.unsrat.ac.id/index.php/administratum/article/view/16428/15925, accessed on March 30, 2020.

${ }^{4}$ Hukum-online.com// penetapan status tersangkah bukan objek peradilan, accessed on March 30, 2020

${ }^{5}$ Annis Nurwianti, Gunarto, Sri Endah Wahyuningsih, Implementasi Restoratif/Reestorative Justice Dalam Penyelesaian Tindak Pidana Kecelakaan Lalu Lintas Yang Dilakukan Oleh Anak Di Polres Rembang, Jurnal Hukum Khaira Ummah Vol. 12. No 4 December 2017
} 
suspect or Beklaagde and defendant or Erdachte have no differentiated meaning and are used with only one term, namely Verdachte. ${ }^{6}$

According to JCT Simorangkir, that the suspect is "someone who has been suspected of having committed a criminal act and this is still at the stage of a preliminary examination to consider whether this suspect has sufficient grounds to be examined at trial. ${ }^{7}$

The terms for the determination of a suspect are regulated in the Criminal Procedure Code which has been further refined by the Constitutional Court (MK) Decision Number 21/PUU-XII/2014 dated April 28, 2015, where the decision explains that Determination of the suspect must be based on:

a. Mat least 2 (two) pieces of evidence as contained in Article 184 KUHAP and

b. Accompanied by the examination of potential suspects.

Article 184 (1) KUHAP, Valid evidence is:

a. Witness testimony;

b. Expert statement;

c. Letter;

d. Instructions;

e. Statement of the defendant.

Operationalization of the criminal justice system in order to achieve the objectives of criminal law enforcement, because it is at the stage of investigation that a suspect in a crime or criminal act is known and determines the suspect who is the perpetrator of the crime or crime before the perpetrator of the crime is finally prosecuted and tried in court and given sanctions. Criminal in accordance with his actions. Likewise with the judicial system which is closely related to other systems in the national legal system. ${ }^{8}$

In processing a person who is suspected of committing a criminal act, the legal process starts from the investigation stage, in the investigation process the person authorized to do this is the investigator, one of the duties and authorities of the investigator is to receive a report or complaint from someone regarding a criminal act in accordance with Article 5. Criminal Procedure Code. The investigator, in this case the police, is in accordance with the provisions of Article 1 point 4 of the Criminal Procedure Code, on the report or complaint looks for and finds an event that is suspected of being a criminal act in order to determine whether or not an investigation can be carried out. Furthermore, after the investigation process is complete, an investigation can be carried out. Investigation based on Article 1 point 2 of the Criminal Procedure Code are:

"A series of investigative actions in terms and according to the manner regulated in this law to seek and collect evidence with this evidence sheds light on the criminal act that occurred and in order to find the suspect."

Investigation as referred to in Article 1 point 2 of the Criminal Procedure Code is in accordance with the meaning of opsporing or interrogation. According to de Pinto, investigating (opsporing) means the preliminary examination by officials

\footnotetext{
${ }^{6}$ C.S.T. Kansil \& Cristine ST Kansil, 1984, Hukum Tata Negara RI Section I, Rineka Cipta, Jakarta, p. 191-192

${ }^{7}$ J.C.T. Simorangkir, dkk, 1983, Kamus Hukum, Pen. Aksara Baru, Jakarta, p. 178

${ }^{8}$ Sudikno Mertokusumo, 2011, Kapita Selekta Ilmu Hukum, Penerbit Liberty, Yogyakarta, p. 19-20
} 
who are for this purpose appointed by law as soon as they in any way hear the news which simply pretends that something has been violated by law. ${ }^{9}$

Based on Article 1 number 14 of the Criminal Procedure Code (KUHAP), what is meant by a suspect is a person who because of his actions or circumstances, based on preliminary evidence, is reasonably suspected of being the perpetrator of a criminal act, in which case the investigation process is not aimed at determining the case. a criminal act or not, but because an investigation is aimed at finding and gathering evidence in order to find the perpetrator of a criminal act or the suspect.

Furthermore, in Article 66 paragraph (1) and paragraph (2) Chief of Police Regulation Number 12 of 2009 concerning Supervision and Control of Criminal Case Handling within the State Police of the Republic of Indonesia (Reg. 12/2009) states that:

(1) An investigator can only determine the status of a suspect to a person after the results of the investigation carried out have obtained sufficient preliminary evidence, namely at least 2 (two) types of evidence.

(2) In order to determine whether to obtain sufficient preliminary evidence, namely at least 2 (two) types of evidence as referred to in paragraph (1) shall be determined by means of a case title.

According to the opinion of AKP Sudarno, SH Kasatreskrim Polres Pati, that in order to assess that the arrest and detention of a suspect by investigators or other law enforcement officers is in accordance with human rights principles, the parameters used are 3 (three) principles of a human rights perspective regarding the determination of the suspect is as follows: ${ }^{10}$

a. The principle of Legality. The arrest and detention of a suspect or defendant is only legal and does not violate human rights if it is carried out by an official who is given the authority to do so. Even though the perpetrator of the crime is a recidivist and the crimes committed are serious crimes such as terrorism, genocide and crimes against humanity, an arrest must still be made by an official who does not have the authority to do so, namely an investigator or investigator on the orders of the investigator. Meanwhile, detention is carried out by investigators, public prosecutors and judges. If the official who makes the arrest or detention does not have the authority to do so, then the state has violated the rights to freedom and independence of individual citizens.

b. The principle of Nesity. It must be admitted that this principle is rarely used by law enforcement officials to judge whether their actions are in accordance with human rights principles. Even at the police level this principle is limited in scope to the use of firearms. Arrest and detention, this principle is rarely used as a basis by law enforcers so that the actions taken take into account and comply with the principles of human rights.

c. The principle of Proportionality. The essence of this principle is that there is a balance between restrictions on the freedom or independence of a suspect or defendant and the objectives to be achieved from arrest and detention, namely gathering evidence and facilitating the judicial examination process. State officials who are given the power to arrest and detain a suspect or defendant

\footnotetext{
${ }^{9}$ R. Tresna, 2000, Komentar HIR, Pradnya Paramita, Jakarta, p. 72

10 Interview with AKP Sudarno, Kasatreskrim Polres Pati, on July 20, 2020
} 
must make the main purpose of arrest and detention as the basis for arresting or detaining someone. If evidence can be obtained without having to arrest the suspect or defendant, the investigator, public prosecutor or judge may not make an arrest or detain. If a defendant whether or not there is any guarantee from his family or other parties is ready to attend an examination at the level of investigation, prosecution, or examination in court, he may not be detained. Detention has implications for limiting the right to physical and psychological freedom and is not directly proportional to the main purpose of detention.

Efforts to maintain the safety of human existence as a whole through balance action between individual interests and public interests. Act No. 39 of 1999 concerning Human Rights, Chapter I General Provisions, Article 1 paragraph (1) explains that:

Human rights are a set of rights that are inherent in the nature and existence of humans as the being of God Almighty and are His gifts that must be respected, upheld and protected by the state, law, government, and everyone for the honor and protection of human dignity. .

Likewise, efforts to respect, protect and uphold human rights are shared obligations and responsibilities among individuals. Government (both civilian and military government apparatus) and the State. ${ }^{11}$ Objectively, the principles of protection of human rights between countries are the same, but subjectively it is not the case, meaning that at one time there is a similarity in what should be protected and regulated, but at the same time there are differences in perceptions of human rights between countries one another. ${ }^{12}$

\subsection{Constraints faced by law enforcers in determining suspects in the process of investigating criminal cases according to the criminal procedure law are in the perspective of protecting human rights and their solutions}

In realizing law enforcement, a good and systematic process chain is needed. For the sake of the realization of the law enforcement process, a good coordination relationship between officials and between law enforcement agencies is needed, in this case the police and prosecutors, guided by the provisions of the prevailing laws and regulations and based on implementation instructions as well as technical instructions in each agency. . One of the things that determines the upholding of the rule of law is the result of the investigation process carried out by the Indonesian Police Investigator (Polri) in terms of gathering evidence so that it can be known the type of criminal act that occurred and the purpose for finding the suspect.

The results showed that the obstacles in the process of investigating and investigating banking criminal cases, which were contained in the Police Report

\footnotetext{
11 A.Bazar Harapan, 2006, Nawangsih Sutardi, Hak Asasi Manusia dan Hukumnya, CV. Yani's, Jakarta, p. 33-34

${ }^{12}$ Muhammad Amin Putra. Eksistensi Lembaga Negara Dalam penegakan Ham Di Indonesia. Fiat Justisia Jurnal Ilmu Hukum. Vol 9. No 3. 2015. p. 4
} 
Number: LP/B/93/I/2020/Jateng/Res PT, January 30, 2020, cases of banking crimes at the Police Pati, Central Java are: ${ }^{13}$

a. The suspect often gives complicated information in front of the investigator, and often removes evidence, this will take time to reveal a criminal act that was committed.

b. The often not timely summons of victim witnesses and expert witnesses;

c. Lack of budget support for handling criminal cases.

Likewise, law enforcers, in this case investigators are ordinary human beings, who cannot be separated from mistakes and mistakes, so that in carrying out their duties and obligations sometimes the suspect/defendant suffers physically and mentally, this is of course a violation of human rights.

The importance of increasing the professionalism of investigators in conducting investigations is to reduce the occurrence of violations that deviate from their duties and functions. The duties and obligations carried out by an investigator are a big responsibility because an investigative action is the beginning of the examination process of a criminal case, everything that an investigator does in the investigation process will have an influence on the subsequent law enforcement process therefore the investigation process can be said to be the end, spear from conducting an examination of a case.

The Criminal Procedure Code has created a control mechanism for law enforcers in carrying out their duties to always focus and improve work professionalism so that there are no procedural errors, which actually violate human rights that have been protected by the 1945 Law in general and the Criminal Procedure Code, namely the existence of a pre-trial institution.

Based on the aforementioned constraints, the authors provide the following solutions in determining the status of a suspect to a person suspected of being the perpetrator of a criminal act committed by the police based on the provisions stipulated in Act No.8 of 1981 concerning Criminal Procedure Law. The law only regulates the requirements (which are considered multiple interpretations), which must be fulfilled in order to determine the status of a suspect to a person suspected of being the perpetrator. Article 1 number 14, Article 17 and Article 21 of the Criminal Procedure Code which basically states that to determine a suspect, at least two pieces of evidence must be fulfilled. However, there is no set limit for the length of time a person has the status of a suspect. Because there is no set time limit for a person to become a suspect, there is a potential for human rights violations to occur.

The solution is:

a. In the future, it is necessary to have operational funds for witnesses who are summoned to give their testimonies so that they can facilitate the investigation process.

b. The need for rules that limit the length of time a person has the status of a suspect, in addition to preventing potential human rights violations, also to provide legal certainty to the justice-seeking community.

\section{Closing}

13 Interview with AKP Sudarno, Kasatreskrim Polres Pati, on July 20, 2020 
Whereas the legality of the determination of a suspect in the investigation process can be recognized in accordance with the SOP, KUHAP regarding the meaning of the investigation and investigation process and the Chief of Police Regulation Number 12 of 2009 concerning Supervision and Control of Criminal Case Handling within the State Police of the Republic of Indonesia regarding the determination of the status of the suspect, the rights of the suspect are fulfilled. The investigator's status as a suspect can only be determined by an individual after the results of the investigation carried out have obtained sufficient initial evidence, namely at least 2 (two) types of evidence. In order to determine whether to obtain sufficient preliminary evidence, namely at least 2 (two) types of evidence as referred to in paragraph (1) shall be determined by means of a case title.

Investigators should consider the human rights of suspects and defendants not only using the principles contained in the criminal procedure law, such as the principle of equality before the law, the principle of presumption of innocence and the principle of providing legal assistance, but it is hoped that investigators must also consider the rights human rights obtained by the suspect and defendant based on the conscience of the investigator.

\section{References}

\section{Books:}

[1] A.Bazar Harapan and Nawangsih Sutardi, 2006, Hak Asasi Manusia dan Hukumnya, CV. Yani's, Jakarta.

[2] C.S.T.Kkansil \& Cristine ST Kansil, 1984, Hukum Tata Negara RI Section I, Rineka Cipta, Jakarta

[3] Erni Widhayanti, 1998, Hak-Hak Tersangka/Terdakawa di Dalam KUHAP, Liberty Yogyakarta

[4] J.C.T. Simorangkir, dkk, 1983, Kamus Hukum, Pen. Aksara Baru, Jakarta

[5] R. Tresna, 2000, Komentar HIR, Pradnya Paramita, Jakarta.

[6] Sudikno Mertokusumo, 2011, Kapita Selekta Ilmu Hukum, Penerbit Liberty, Yogyakarta

\section{Journals:}

[1] Annis Nurwianti, Gunarto, Sri Endah Wahyuningsih, Implementasi Restoratif/Reestorative Justice Dalam Penyelesaian Tindak Pidana Kecelakaan Lalu Lintas Yang Dilakukan Oleh Anak Di Polres Rembang, Jurnal Hukum Khaira Ummah Vol. 12. No 4 December 2017.

[2] Muhammad Amin Putra. Eksistensi Lembaga Negara Dalam penegakan Ham Di Indonesia. Fiat Justisia Jurnal Ilmu Hukum. Vol 9. No 3. 2015.

\section{Regulations:}

[1] Act No. 8 of 1981 concerning KUHAP (Criminal Procedure Code.

[2] Act No. 39 of 1999 concerning Human Rights.

[3] The National Police of the Republic of Indonesia Circular SE/8/VII/2018, Regarding the Application of Restorative Justice in Criminal Case Resolution.

[4] Regulation of the Head of the National Police of the Republic of Indonesia Number 6 of 2019 concerning Criminal Investigation. 


\section{[5] Internet:}

[6] https://media.neliti.com/media/publications/12327-ID-tinjauan-yuridis-hakhak-tersangka-dalam-pemeriksaan-pendahuluan.pdf, Accessed on 29 March 2020.

[7] Hukum-online.com//penetapan status tersangkah bukan objek peradilan, Accessed on 30 Maret 2020.

\section{Interview:}

Interview with AKP Sudarno, Kasatreskrim Polres Pati, on July 20, 2020 